\title{
The effects of fruit availability and habitat disturbance on an assemblage of Sumatran hornbills
}

\author{
KIKI ANGGRAINI, MARGARET KINNAIRD and TIMOTHY O'BRIEN
}

\begin{abstract}
Summary
We examined the influence of fruit availability and habitat disturbance, including past and recent forest fires, on an assemblage of hornbills over a four-month period in the Bukit Barisan Selatan National Park, Sumatra. The assemblage is dominated by Wreathed Hornbills Aceros undulatus $\left(7.5\right.$ birds $\left./ \mathrm{km}^{2}\right)$, followed by Bushy-crested Hornbills Anorrhinus galeritus ( 3.05 birds $/ \mathrm{km}^{2}$ ), Rhinoceros Hornbills Buceros rhinoceros (2.6 birds/ $\mathrm{km}^{2}$ ), and Helmeted Hornbills Buceros vigil (1.9 birds $/ \mathrm{km}^{2}$ ). Overall densities for each species were consistent with estimates from other South-East Asian sites but densities varied temporally and spatially, even for territorial species. We speculate that Rhinoceros and Helmeted Hornbills may exhibit facultative territoriality or they may not be territorial at this site. We found a positive relationship between temporal variability in hornbill numbers and the availability of ripe fruits. All hornbills, especially Rhinoceros and Bushy-crested Hornbills, tended to avoid highly disturbed areas; these areas had a lower than expected number of fruiting trees in five important hornbill diet families. Densities of Bushy-Crested, Rhinoceros, and Helmeted Hornbills declined from 28 to $63 \%$ in the post-burn surveys. Wreathed Hornbills, however, increased slightly in the post-burn surveys, possibly because they were nesting there at the time. Movement of hornbills between disturbed and primary forest habitat may enhance regeneration of disturbed areas if hornbills are transporting viable seeds.
\end{abstract}

\section{Introduction}

Forest size, habitat structure, and the abundance and distribution of fruit resources have been shown to strongly influence the density and distribution of Asian hornbills (Poonswad and Kemp 1993, Kemp 1995, Kinnaird et al. 1996). All Asian hornbills are forest specialists and tend to prefer large tracts of primary forest habitat (Inskipp and Inskipp 1985, Kemp 1995, Kinnaird et al. 1996). O'Brien et al. (1998) demonstrated that the endemic Sumba Island Hornbill Aceros everetti is rare or absent in forest patches less than 1,00o ha in size and Suryadi et al. (1998) presented data that suggested the Sulawesi Red-knobbed Hornbill Aceros cassidix uses home ranges in excess of 5,000 ha. Hornbills tend to be adversely affected by habitat disturbance, including logging, forest fires and other natural disturbances (Johns 1983, 1987, Kinnaird and O'Brien 1998, Cahill and Walker 2000). Although selective logging does not necessarily result in declining hornbill densities (Lambert pers. comm.), proximity of logged habitats to neighbouring, pristine forest refuges may be important for persistence in 
degraded habitats (Johns 1986). Leighton and Wirawan (1986) showed that relative to other species, hornbills declined more dramatically after forest fires. Cahill and Walker (2000) demonstrated a substantial decline in nesting success of the Sulawesi Red-knobbed Hornbills after forest fires.

Highly frugivorous hornbills require larger home ranges than more carnivorous hornbills of comparable body size (Leighton 1982, 1986, Kemp 1995). Fruit resources tend to be more widely dispersed and unevenly distributed in space, and are more temporally variable than animal prey (Terborgh 1983). Reliance on spatially patchy resources may explain the large home ranges required by Aceros hornbills (Poonswad and Tsuji 1994, Suryadi et al. 1998). Temporal patchiness induced by patterns of fruiting also affects ranging patterns; hornbills tend to travel farther as fruit availability declines and dispersion increases, and restrict their movements as fruit availability increases (Leighton and Leighton 1983, Suryadi et al. 1998). Even in more carnivorous, territorial species, immatures and non-breeding adults may occasionally form flocks that range widely in search of food (Kemp 1995). Rhinoceros Hornbills Buceros rhinoceros and Helmeted Hornbills Buceros vigil, for example, are reported to live as resident, territorial pairs but flocks of subadults and non-breeders may range over hundreds of square kilometres (Kemp 1995).

In this paper, we examine the influence of fruit availability and habitat disturbance on a community of Sumatran hornbills that varies in degree of frugivory and territoriality. We also examine the effect of recent forest fires on hornbill numbers and shifts in habitat use by hornbills in the Bukit Barisan Selatan National Park, Lampung Province, Sumatra.

\section{Methods}

Study area

We conducted our study between 28 July and 13 November 1997 in the Bukit Barisan Selatan National Park (BBSNP), located in the south-western region of Sumatra $\left(4^{\circ} 31^{\prime}-5^{\circ} 57^{\prime} \mathrm{S}\right.$ and $\left.103^{\circ} 24^{\prime}-104^{\circ} 43^{\prime} \mathrm{E}\right)$. BBSNP is the third largest protected area $\left(3,568 \mathrm{~km}^{2}\right)$ in Sumatra and falls within the provinces of Lampung and Bengkulu. The park contains some of the largest tracts of lowland rainforest remaining in Sumatra, as well as examples of hill and montane forest $\left(\mathrm{O}^{\prime}\right.$ Brien and Kinnaird 1996). Annual precipitation ranges from 1,600 $\mathrm{mm}$ in dry years to $4,000 \mathrm{~mm}$ in wetter years with a short dry season generally occurring between June and September (Kinnaird and O'Brien, unpubl. data). The park experiences periodic droughts associated with the El Niño Southern Oscillation (ENSO) (Kinnaird and O'Brien 1998).

The BBSNP supports most of the important large mammals of Sumatra, including Sumatran tiger Panthera tigris sumatrae, Sumatran rhino Dicerorhinus sumatrensis, Malayan tapir Tapirus indicus, Malayan sun bear Ursus malayanus and the Asian elephant Elephus maximus. More than 277 bird species have been observed at BBSNP (O'Brien and Kinnaird 1996 and unpubl. data), including all hornbill species known to occur on Sumatra (Rasmussen in litt. 1999).

Our study site was located on the southern side of the WCS/PHPA Way Canguk Research Area (Figure 1). The site contains approximately 600 ha of 


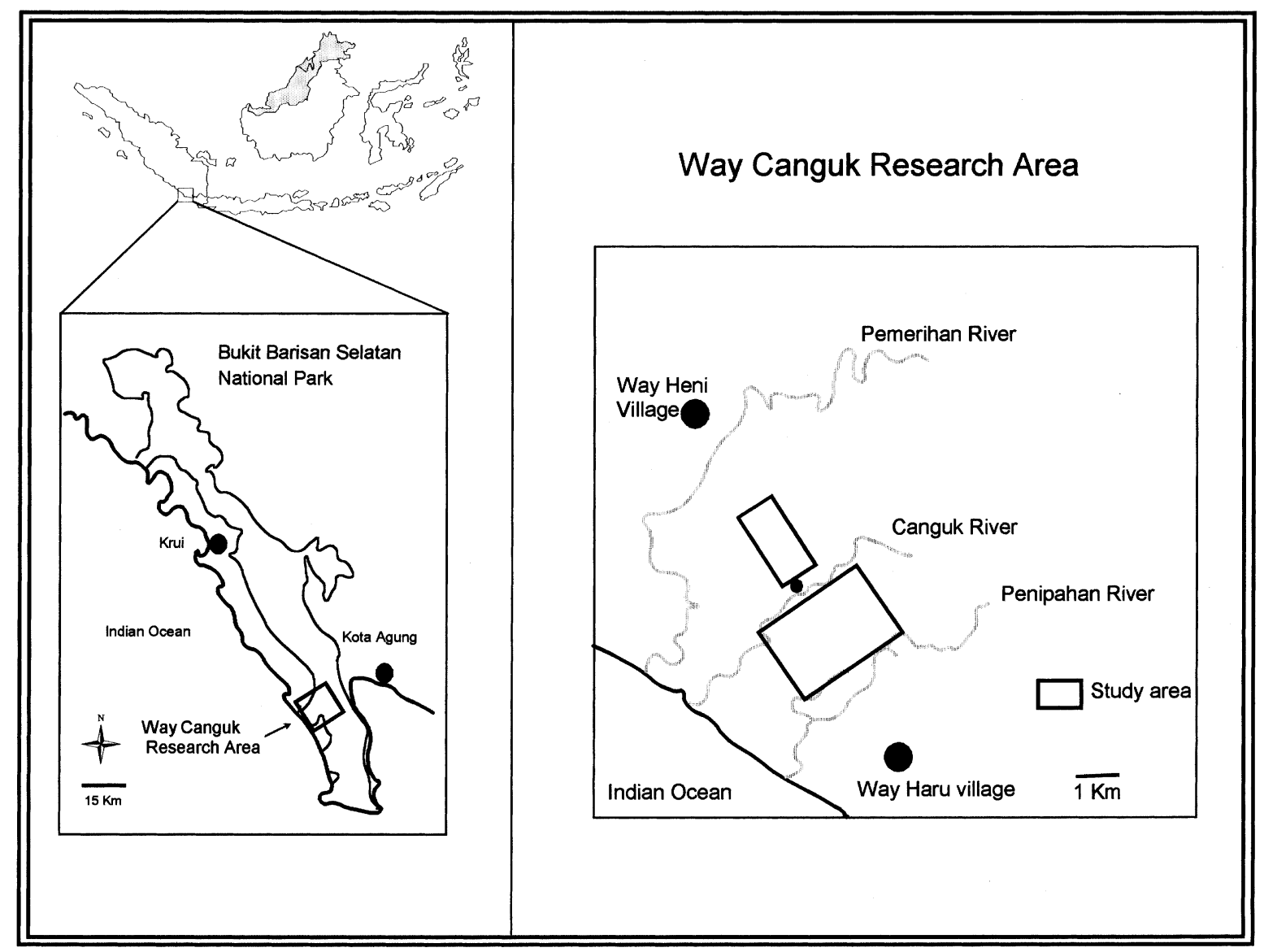

Figure 1. Location of the Way Canguk Research Area in the Bukit Barisan Selatan National Park, Lampung Province, Sumatra. 
lowland forest and is surrounded by a matrix of intact forest, burned forest, areas disturbed by illegal logging and agricultural lands. The major habitat within the nearest $100 \mathrm{~km}^{2}$, however, is primary forest. The study area is contiguous with the lowland and montane forests of the rest of the park and is characterized by varying degrees of disturbance. The forest is classified into five habitats based on structural characteristics and described by Busch et al. (unpubl. report, 1997). The categories include: (1) closed canopy forest, (2) transition forest, (3) broken forest, (4) disturbed forest with few large diameter-breast-height (DBH) trees, and (5) disturbed forest with few small DBH trees (Figure 2). Closed canopy forest covers approximately $21 \%$ of the study area and is characterized by tall trees with large DBH measurements and a relatively closed upper canopy. Transition forest is found over $31 \%$ of the study area and is characterized by a more open canopy and denser understorey than closed canopy forest. Broken forest, covering $26 \%$ of the study area, lies on the gradient between transition and disturbed forest; canopy openness is intermediate between transition and disturbed forest and the understorey is often dominated by herbaceous plants of the family Zingeberaceae. The two most disturbed forest habitats are differentiated primarily by tree size but both habitats are characterized by a history of previous fire (from 1994/95), extremely open canopy and an understory dominated by Zingeberaceae. Together, the two habitats cover approximately $22 \%$ of the study area and were combined during analysis. As a result of ENSO and fires set by local farmers and hunters, approximately 165 ha of the study area burned during our study in late September and October 1997 (O'Brien et al.1997, Kinnaird and O’Brien 1998; Figure 2).

\section{Hornbill abundance and distribution}

We used variable-width line transect surveys (Bibby et al. 1992) to determine the distributions and estimate the densities of hornbill species over a four-month period. Every two weeks, we surveyed 11 transects, each $2 \mathrm{~km}$ in length, and separated by $200 \mathrm{~m}$. Surveys began at approximately o6hoo and ended just after 1ohoo. We surveyed two transects/day, for five days; on the sixth day the final transect was surveyed. In order to minimize the chance of double counting hornbills, daily samples were conducted on alternating transects separated by $400 \mathrm{~m}$. Data collected during the surveys included: (1) hornbill species, (2) number of individuals, (3) detection cue (visual or vocal), (4) location of observer on transect, (5) estimated distance between observer and hornbill, and (6) angle between observer and hornbill.

We used the computer program DISTANCE (Laake et al. 1993) to calculate densities for the four most common hornbill species. First, data were grouped into $20 \mathrm{~m}$ perpendicular distance intervals and evaluated for goodness of fit to detection probability function models. We evaluated uniform, half normal, hazard, or negative exponential with cosine adjustments. We truncated perpendicular distance data for all species at natural breaks in the data distribution to maintain the monotonicity of the detection curve.

To examine the influence of fire and habitat damage on hornbill abundance and distribution, we divided the data into pre- and post-burn survey periods 


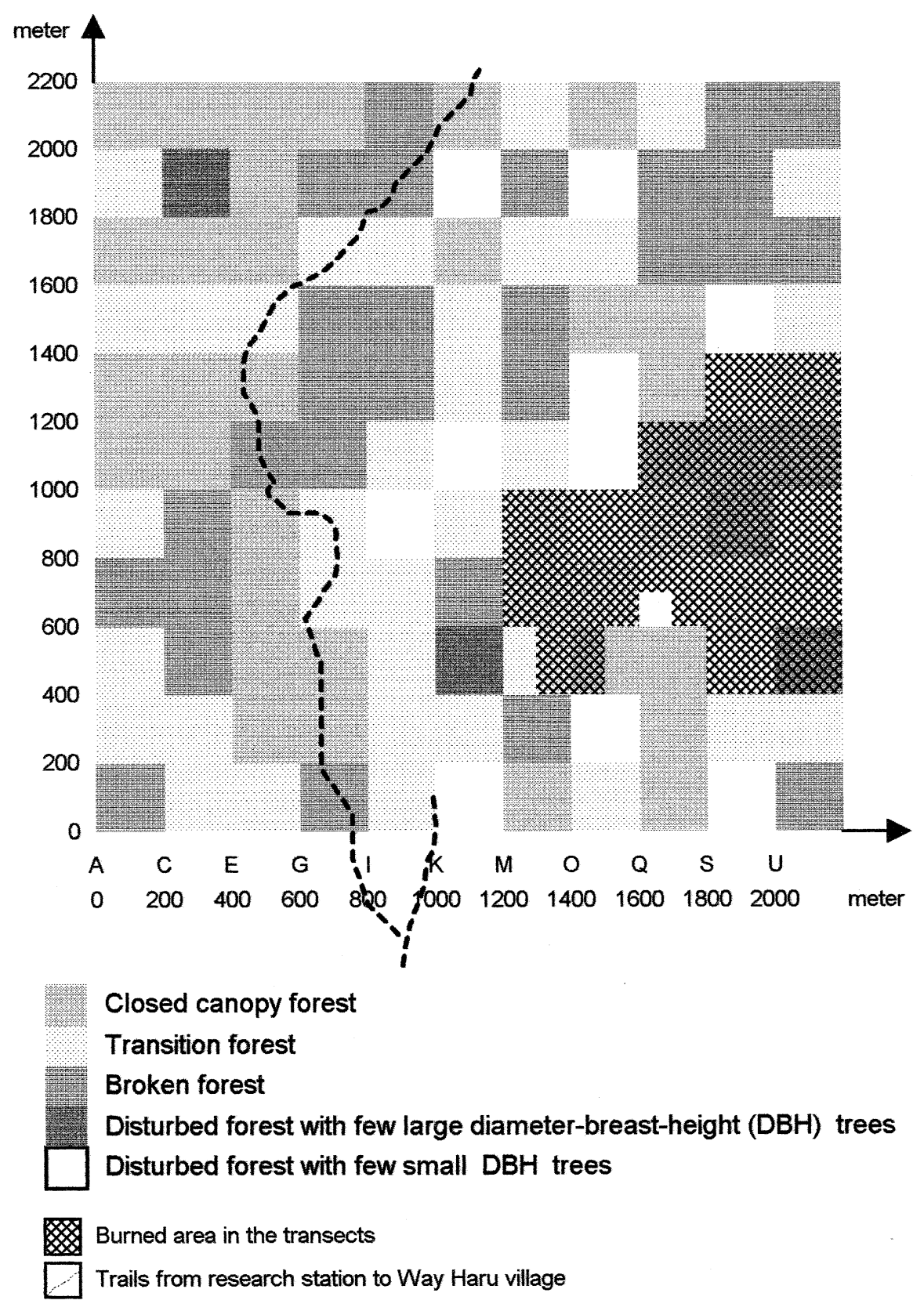

Figure 2. Distribution of habitat types and recently burned forest in the Way Canguk Research Area. 
and compared densities. The pre-burn data set included six bi-weekly surveys, and the post-burn data set included two bi-weekly surveys.

We examined the influence of habitat type on hornbill distribution by plotting all hornbill sightings and summing the frequency of sightings relative to the five habitat types. We used a $\chi^{2}$ analysis to test for differences in the distribution of sightings by habitat type and species. Expected values were generated based on a random distribution of individuals proportional to the amount of each habitat type in the study area.

\section{Fruit availability}

We collected data on patterns of fruiting on a bi-weekly basis to determine the effect of the availability of fruit resources on hornbill abundance and distribution. Phenological surveys were conducted immediately after hornbill surveys were completed on the 11 sample transects. All fruiting trees (except Dipterocarpaceae and wind-dispersed species) within $50 \mathrm{~m}$ of either side of the transects were mapped and assigned a species identification or a species code. Next, we visually estimated the percentage of canopy covered in fruit and divided that estimate into the percentage of ripe and unripe fruit, based primarily on colour changes indicating ripeness. We calculated a bi-weekly estimate of overall canopy cover in fruit by taking the mean for all fruiting trees, regardless of species and further divided this mean into the percentage of canopy containing ripe and unripe fruit.

We tested for differences in distribution of fruiting trees in families known to be important in hornbill diets (Annonaceae, Burseraceae, Meliaceae, Moraceae and Myristicaceae; Leighton 1982) in the different habitat types. We used $\chi^{2}$ analysis to determine if habitat differences in availability of the selected hornbill food trees was consistent with variation in hornbill numbers among habitats. Expected values were generated based on a random distribution of trees proportional to the amount of each habitat type in the study area.

We used multiple regression analysis (Sokal and Rohlf 1981) to examine the relationship between variability in hornbill numbers and the fluctuation in fruit availability. We used hornbill numbers as a variable in the model because sample sizes were too small to calculate hornbill densities for all species on all transects. Hornbill numbers were combined for all species on a transect and regressed against mean canopy cover in fruit and the mean percentage of canopy bearing ripe fruits per transect.

\section{Results}

We observed six species of hornbills on our transects, including the Wreathed Hornbill Aceros undulatus, the Bushy-crested Hornbill Anorrhinus galeritus, the Rhinoceros Hornbill Buceros rhinoceros, the Helmeted Hornbill Buceros vigil, the White-crowned Hornbill Aceros comatus, and the Oriental Pied Hornbill Anthracoceros albirostris. The Great Hornbill Buceros bicornis was seen outside the transects but still within the study area. Only four of these species however, were common enough to calculate density estimates (Table 1 ). Hornbill densities fluctuated over the census periods (Figure 3). Wreathed and Bushy-crested Hornbills fluctuated more dramatically than Rhinoceros or Helmeted Hornbills, with these 
Table 1. Overall, pre- and post-burn densities of four hornbill species in the Bukit Barisan Selatan National Park

\begin{tabular}{llll}
\hline Species & \multicolumn{3}{c}{ Density $\left(\mathrm{birds} / \mathrm{km}^{2}\right)$} \\
\cline { 2 - 4 } & Pre-burn & Post-burn & Overall \\
\hline Wreathed Hornbill Aceros undulatus & 7.4 & 8.3 & 7.5 \\
Bushy-crested Hornbill Anorrhinus galeritus & 3.41 & 2.46 & 3.05 \\
Rhinoceros Hornbill Buceros rhinoceros & 3.13 & 1.17 & 2.6 \\
Helmeted Hornbill Buceros vigil & 2.1 & 1.0 & 1.9 \\
\hline
\end{tabular}

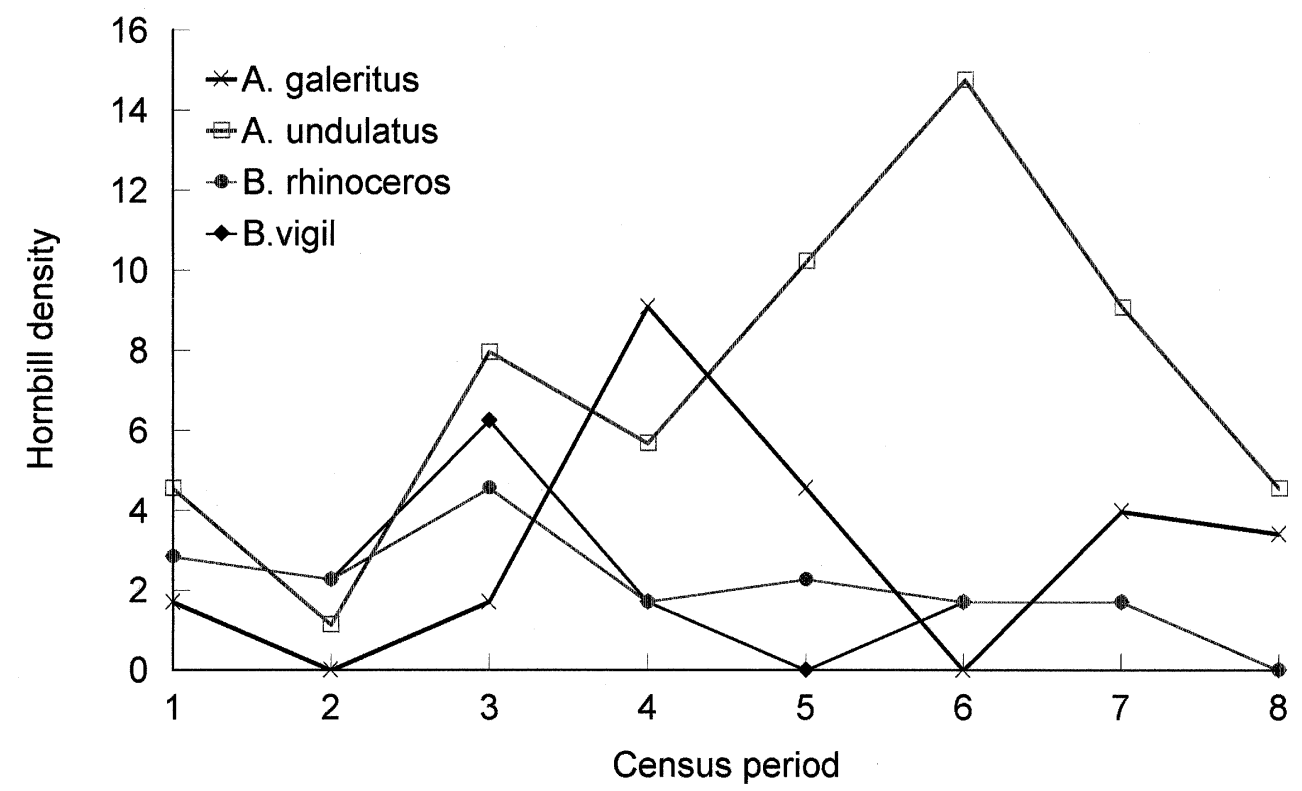

Figure 3. Densities of four hornbill species over eight bi-weekly sample periods.

last two species showing similar patterns of abundance throughout the study and both disappeared from the study area on two occasions (Figure 3).

Multiple regression analysis showed a significant relationship between hornbill abundance and fruit availability:

$y=1.42+0.0063 \times \%$ canopy with ripe fruits $-0.0031 \times \%$ canopy in fruit $\left(F=4.843 ; P=0.0094 ; r^{2}=0.1\right)$.

The model indicates a negative relationship between hornbill numbers and the percentage of canopy in fruit $(P=0.004)$ and a positive relationship between hornbill numbers and the availability of ripe fruit $(P=0.05)$. Typically, as a tree ripens, the percentage of ripe fruit increases while the percentage of total fruit decreases due to harvest and fruit fall.

Hornbills were found in every habitat type, although the species were not distributed randomly among habitats $\left(\chi^{2}=40.49, d f=9, P<0.001\right.$; Figure 4$)$. There were greater than expected numbers of Bushy-crested, Wreathed and Rhinoceros 

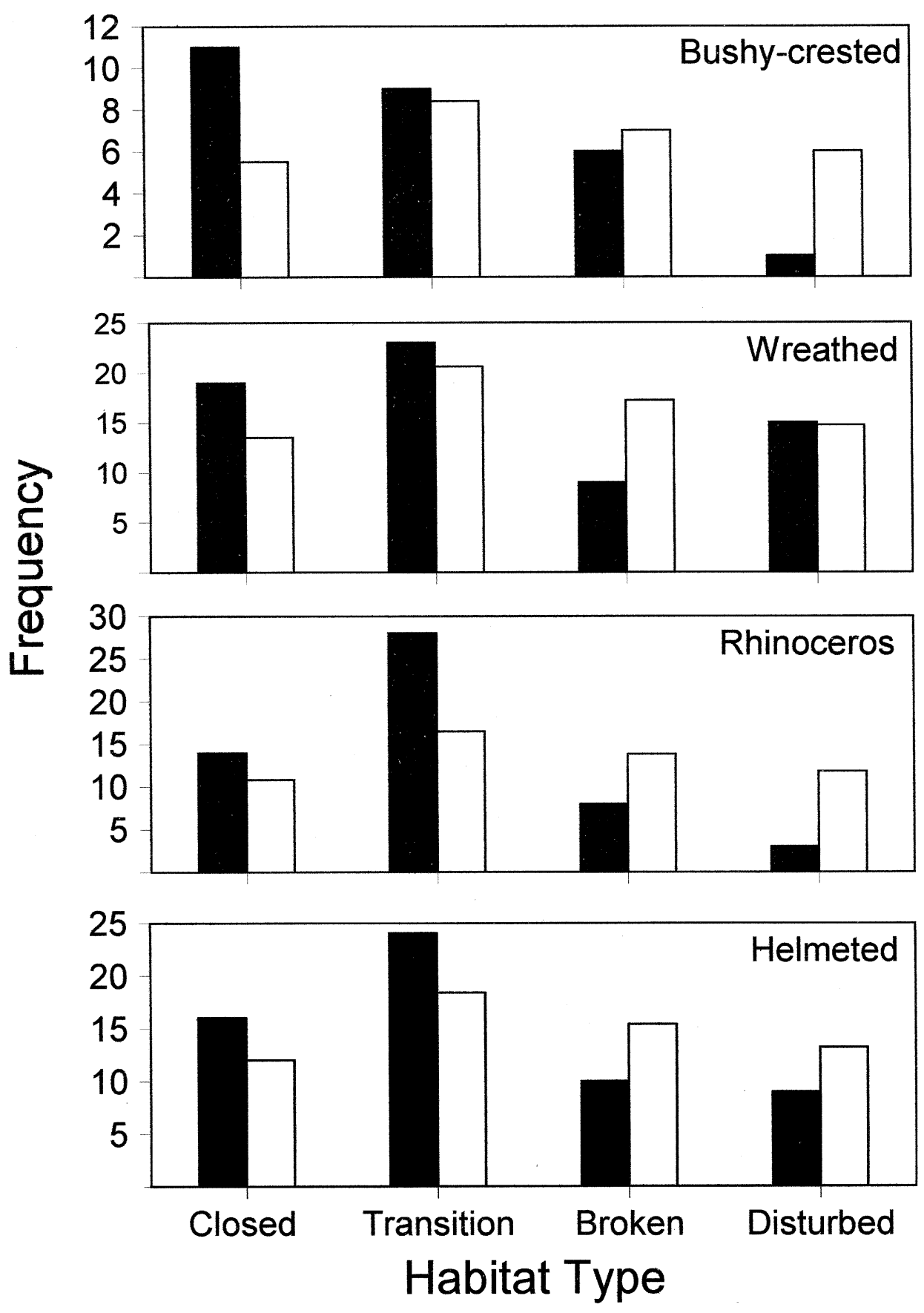

Figure 4. Observed (filled bars) and expected (open bars) sightings of four hornbill species by habitat type. 
Hornbills in closed canopy forest and lower than expected numbers of Rhinoceros and Helmeted Hornbills in broken and disturbed forest.

As expected, fruiting trees of the families Annonaceae, Burseraceae, Meliaceae, Moraceae and Myristicaceae were not evenly distributed among habitat types $\left(\chi^{2}=141.02, d f=12, P<0.001\right.$; Figure 5$)$. All families occurred more often than expected in closed canopy forest and less than expected in highly disturbed forests. Trees in the Meliaceae and Annonaceae families occurred less than expected in transition and broken habitats, while the Moraceae, mostly fig trees, occurred more than expected in transition and less than expected in the broken habitat.

The immediate effects of fire and the resulting alteration of habitat had mixed effects on hornbill densities. Densities of Bushy-crested, Rhinoceros, and Helmeted Hornbills declined from 28 to $63 \%$ in the post-burn surveys (Table 1). Wreathed Hornbills, however, increased by over $11 \%$ in the post-burn surveys (Table 1).

\section{Discussion}

\section{Fruit resources}

The hornbill community of the Way Canguk Research Area is dominated by four species, ranging in density from 1.9 individuals $/ \mathrm{km}^{2}$ for Helmeted Hornbills to 7.5 individuals $/ \mathrm{km}^{2}$ for Wreathed Hornbills (Table 1 ). Our density estimates and fluctuations in hornbill numbers broadly agree with expectations based on social systems, territoriality and known responses of hornbills to food supply (Leighton 1982,1986, Kemp 1995, Kinnaird et al. 1996). Rhinoceros and Helmeted Hornbills are believed to occur in territorial pairs at low densities in primary and secondary forest (1 pair/0.5-3.0 km² to 1 pair/1.8-8.o $\mathrm{km}^{2}$ for Rhinoceros and Helmeted Hornbills, respectively; Kemp 1995). Kemp (1995) suggests that fluctuations in densities for these species can be attributed primarily to subadult and nonbreeding adults moving through the area. Our data suggest that these movements may be in response to variation in food availability; as ripe fruits increase in the canopy, birds are attracted to the area for several weeks at a time. Contrary to reports by Kemp (1995) and Leighton (1982), we did not observe flocks of Rhinoceros and Helmeted Hornbills in the study area. Our study area, however, is small relative to the potential home ranges of these birds, and flocks may have occurred undetected in surrounding areas. Nonetheless, all observations during systematic surveys were of single and paired individuals, indicating that the passage of flocks was not a factor in density variability within the study area.

We believe the territorial behaviour of Helmeted and Rhinoceros Hornbills may break down when large fig trees fruit within their territories. Incidental observations of hornbills feeding in large fig trees were of several pairs feeding in the same tree; pairs moved independently of one another and did not exhibit the coordinated movements of a flock. Figs dominate the diets of both hornbill species in Way Canguk, accounting for $90 \%$ and $70 \%$ of all feeding records for Helmeted and Rhinoceros Hornbills, respectively (Hadiprakarsa and M.K. unpubl. data). However, fig trees occur at low densities in the study area (0.51 reproductive figs/ha) relative to other sites in Peninsular Malaysia (2.o figs/ha, Johns 1983) and Kalimantan (6.6 figs/ha, Leighton 1982) where these hornbills 

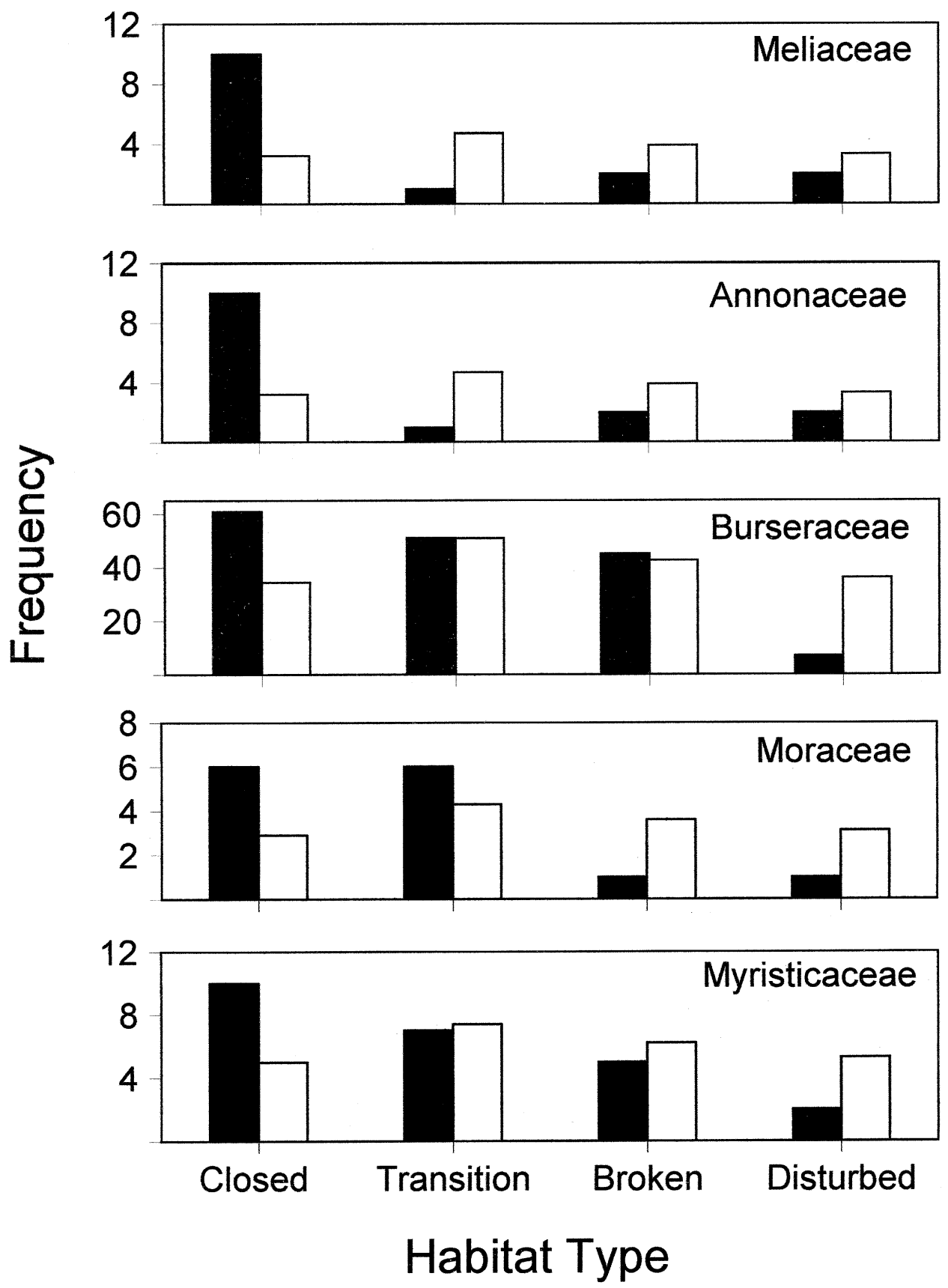

Figure 5. Observed (filled bars) and expected (open bars) distribution of fruiting trees for families of important diet species by habitat type. 
have been studied. We speculate that Rhinoceros and Helmeted Hornbills may practice facultative territoriality, or variable resource defence, characteristic of some primates (Butynski 1990, Kinnaird 1992). Species exhibiting facultative territoriality, or variable resource defence, exhibit territoriality only when resources are limiting and defendable (Kinnaird 1992). Given the well-known, asynchronous fruiting patterns of figs, a higher density of reproductive fig trees than is present at Way Canguk may be required to provide a consistent and defendable resource base for a hornbill relying almost exclusively on figs. Alternatively, these species may not be territorial at this site. Our observations of Rhinoceros and Helmeted Hornbills disappearing from the study site reinforce this idea.

Bushy-crested Hornbills occur at average densities relative to sites in Malaysia and Borneo (Leighton 1982, Whitmore 1984, Johns 1987). Our data support the view that Bushy-crested Hornbills are group living and strictly territorial (Kemp 1995). Observations of Bushy-crested Hornbills were clustered into discrete areas and observations were of consistent group sizes. Additionally, we never encountered more than one group at a fruiting tree. The observed increase in density during the fourth survey period may be a result of double counting one group that was ranging over several transects during the sample period.

Wreathed Hornbills occurred at the highest average density of all species recorded at Way Canguk. Similar to other Aceros species, Wreathed Hornbills are highly frugivorous and their numbers fluctuate over time in response to changes in ripe fruit availability (Suryadi et al. 1994, Kinnaird et al 1996). Poonswad and Tsuji (1994) and Suryadi et al. (1998) show that Aceros hornbills have the largest home ranges of any of the hornbill species for which we have data. Suryadi et al. (1998) speculated that large ranges were necessary to exploit widely dispersed fruit resources. We suspect that fluctuations in densities of Wreathed Hornbills in Way Canguk are due primarily to individuals moving in and out of the study area and not large flocks of birds. Observations of Wreathed Hornbills were generally as singles or pairs and occasionally as groups of three. Only once in the three years after this study was conducted has a flock of 30 individuals, primarily juveniles, been observed.

\section{Habitat disturbance}

Hornbill species showed varying levels of tolerance to disturbed habitats and response to recent forest fires. Our data indicate that all four common species in Way Canguk avoid highly disturbed, open habitats and this avoidance is consistent with the distribution of fruiting trees in families of important diet species (Figure 4, 5). Bushy-crested Hornbills showed the strongest preference for closed canopy forest and the strongest avoidance of the highly disturbed habitats. Wreathed and Rhinoceros Hornbills showed the next strongest preference for higher quality habitats. Helmeted Hornbills showed similar preferences although they were the least pronounced. Hornbills may avoid the more disturbed habitats due to lower fruiting and severe structural damage to the canopy. In addition to the demonstrated differences in the abundance of fruiting trees by habitat, phenological data for Way Canguk (K.A. unpubl. thesis, 1999) suggest that trees in the disturbed habitats have smaller fruit crops than trees in closed canopy forest. Reduced availability of fruit makes disturbed habitats less attractive for 
all species. Although Bushy-crested Hornbills rely less on fruit than the other hornbills, lower stem densities in the disturbed habitats results in an open midcanopy, making the habitat unfavourable for them; Bushy-crested Hornbills are known to favour dense forests with a well-developed mid-canopy and are scarce in open habitats (van Marle and Voous 1988, Kemp 1995).

The short-term effects of habitat disturbance are demonstrated by the effects of fire on the four hornbill species. All species moved away from the burned area during and after the fires and densities of three species declined throughout the study area. Hornbills are highly mobile species (Poonswad and Tsuji 1994, Kemp 1995, Suryadi et al. 1998) and would be expected to avoid the smoke and haze associated with forest fires. Interestingly, Wreathed Hornbill densities showed a slight increase post-fire, indicating the fires did not affect them. We believe their lack of response was due to the fact that pairs were nesting there at the time, including two pairs close to the boundary of the burn. Cahill and Walker (2000) showed that Sulawesi Red-knobbed Hornbills were reluctant to abandon nests once the female had sealed even when fires scorched the tree.

If highly disturbed, burned forests are adjacent to primary forest and retain large trees that provide nest sites or preferred food resources such as figs, these areas may still be attractive to hornbills (Kalina 1988, Kinnaird and O'Brien 1999). Movement of hornbills between disturbed and primary forest may enhance regeneration of disturbed areas if hornbills are transporting viable seeds (Kinnaird et al. 1996). Kinnaird (1998) reported Sulawesi Red-knobbed Hornbills carried seeds up to $6 \mathrm{~km}$ and those seeds germinating under nest trees survived at least 12 months. This underscores the importance of highly mobile, frugivorous birds such as hornbills as agents of forest regeneration, particularly after severe forest fires.

\section{Acknowledgements}

This work was conducted under the auspices of the Wildlife Conservation Society: Indonesia Program in collaboration with the Indonesian Directorate General for Protection and Conservation of Nature (PKA). We thank the Wildlife Conservation Society for funding our research and Pak Sampurno for granting permission to conduct research in the Bukit Barisan Selatan National Park. We warmly acknowledge our technicians, Mr Marwoto, Mr Risdianto, Mr Suyadi, and Mr Teguh Prianto for assistance in data collection, and Mr. Sunarto for logistical support as manager of the Way Canguk Research Station. Mr Willi Rombang, Ms C. Reid, Ms D. Busch, Mr A. Goodman, Ms S. Henry, and $\mathrm{Mr} \mathrm{H}$. Hull provided invaluable camaraderie and stimulating conversation during all phases of field work.

\section{References}

Bibby, C. J., Burgess, N. D. and Hill, D. A. (1992) Bird census techniques. London: Academic Press.

Butynksi,T. (1990) Comparative ecology of blue monkeys (Cercopithecus mitis) in high- and low-density subpopulations. Ecol Monogr. 60:1-26.

Cahill, A. J. and J. S. Walker (2000) The effects of forest fire on the nesting success of the Red-knobbed Hornbill Aceros cassidix. Bird Conserv. Internatn. 10: 109-114.

Inskipp, C. and Inskipp, T. (1985) A guide to the birds of Nepal. London: Croom Helm. 
Johns, A. (1983) Ecological effects of selective logging in a West Malaysian rain forests. PhD dissertation, Cambridge University.

Johns, A. D. (1986) Effects of selective logging on the ecological organization of a peninsular Malaysian rainforest avifauna. Forktail 1: 65-79.

Johns, A. D. (1987) The use of primary and selectively logged rainforest by Malaysian hornbills (Bucerotidae) and implications for their conservation. Biol. Conserv. 40: 179190.

Kalina, J. (1988) Ecology and behavior of the Black-and-white Casqued Hornbill (Bycanistes subcylindricus subquadratus) in Kibale Forest, Uganda. PhD dissertation, Michigan State University, Lansing, MI.

Kemp, A. (1995) Bird families of the world: the hornbills, Bucerotiformes. Oxford: Oxford University Press.

Kinnaird, M. F. (1992) Variable resource defense by the Tana River crested Mangabey. Behav. Ecol. Sociobiol. 31: 115-122.

Kinnaird, M. F. (1998) Evidence for effective seed dispersal by the Sulawesi Red-knobbed Hornbill, Aceros cassidix. Biotropica 30: 50-55.

Kinnaird, M. F. and O'Brien, T. G. (1998) Ecological effects of wildfire on lowland rainforest in Sumatra. Conserv. Biol.12: 954-956.

Kinnaird, M. F. and O'Brien, T. G. (1999) Breeding ecology of the Sulawesi Red-knobbed Hornbill, Aceros cassidix. Ibis 141: 60-69.

Kinnaird, M. F, O'Brien, T. G. and Suryadi, S. (1996) Population fluctuation in Sulawesi Red-knobbed Hornbills: tracking figs in space and time. Auk 113: 431-440.

Laake, J. L., Buckland, S. T., Anderson, D. R. and Burnham, K. P. (1993) DISTANCE user's guide, version 2.o. Fort Collins, CO: Colorado Cooperative Fish and Wildlife Research Unit, Colorado State University.

Leighton, M. (1982) Fruit resources and patterns of feeding, spacing and grouping among sympatric Bornean hornbills (Bucerotidae). PhD dissertation, University of California, Davis.

Leighton, M. (1986) Hornbill social dispersion: variations on a monogamous theme. Pp. 108-130 in D. Rubenstein and R. W. Wrangham, eds. Ecological aspects of social evolution. Princeton: Princeton University Press.

Leighton, M. and Leighton, D. R. (1983) Vertebrate responses to fruiting seasonality within a Bornean rain forest. Pp. 181-196 in S. L. Sutton, T. C. Whitmore and A. C. Chadwick, eds. Tropical rainforest: ecology and management. Oxford: Blackwell Scientific Publications.

Leighton, M. and Wirawan, N. (1986) Catastrophic drought and fire in Borneo tropical rainforest associated with the 1982-1983 El Niño Southern Oscillation event. Pp. 75-102 in Tropical rain forests and the world atmosphere. American Association of the Advancement of Sciences (AAAS) symposium 101. Boulder: Westbury Press.

O'Brien, T. and Kinnaird, M. (1996) Birds and mammals of the Bukit Barisan Selatan National Park, Sumatra, Indonesia. Oryx 30: 207-217.

O'Brien, T. G., Kinnaird, M. F., Sunarto, Dwiyahreni, A. A., Rombang W. M. and Anggraini, K. (1997) Effects of the 1997 fires on the Bukit Barisan Selatan National Park, Sumatra. Bronx, N. York:Wildlife Conservation Society (Working papers series 13).

O'Brien, T. G., Kinnaird, M. F. Jepson P., and Setiawan I. (1998). Effect of forest size and structure on the distribution of Sumba Wreathed Hornbills, Aceros everetti. Pp. 209-218 in P. Poonswad, ed. The Asian hornbills: ecology and conservation. Bangkok, Thailand: Thai Studies in Biodiversity 2.

Poonswad, P. and Kemp, A. (1993) Manual to the conservation of Asian hornbills. Bangkok: Sirivatana Interprint.

Poonswad, P. and Tsuji, A. (1994) Ranges of males of the Great Hornbill Buceros bicornis, Brown Hornbill Ptelolaemus tickelli and Wreathed Hornbill Rhyticeros undulatus in Khao Yai National Park, Thailand. Ibis 136: 79-86. 
Sokal, R. R. and Rohlf, F. J. (1981) Biometry. Second edition. San Francisco: W. H. Freeman. Suryadi, S., Kinnaird, M. F., O’Brien, T. G., Supriatna J., and Somadikarta S. (1994) Food preferences of the Sulawesi Red-knobbed Hornbill during the non-breeding season. Trop. Biodivers. 2: 377-384.

Suryadi, S., Kinnaird, M. F. and O'Brien T. G. (1998) Home ranges and daily movements of the Sulawesi Red-knobbed Hornbill during the non-breeding season. Pp. 159-170 in P. Poonswad, ed. The Asian hornbills: ecology and conservation. Bangkok: Thai Studies in Biodiversity 2.

Terborgh, J. (1983) Five New World primates: a study in comparative ecology. Princeton: Princeton University Press.

van Marle, J. G. and Voous, K. H. (1988) The birds of Sumatra. London: British Ornithologists' Union (Check-list 10.).

Whitmore, T. C. (1984) Tropical rainforests of the Far East. 2nd edition. Oxford: Clarendon Press.

KIKI ANGGRAINI,

Universitas Indonesia, Fakultas Matematika dan Ilmu Pengetahuan Alam, Depok, Indonesia.

MARGARET KINNAIRD* and TIMOTHY O'BRIEN

Wildlife Conservation Society-Indonesia Program, P.O. Box 311, Bogor 16003, Indonesia; e-mail: wcs-ip@indo.net.id

* Corresponding author 